hind tibiae white.

Abdomen black above, with three rows of gray-white spots, the median spots on second to fifth tergites triangular, nearly the length of the tergites; sublateral ovate spots oblique, slightly tinged with yellow, not reaching hind margin. Venter grayish black with a shiny black ventral line.

Holotype.--Female, Matsumoto, Nagano Pref, 20 Jun. 1956, collected by A. Yajima.

Paratype.-A female, Aomori, 10 Jul. Coll.
Sumiyoshi.

Holotype is preserved in the National Institute of Animal Health, Kodaira, Tokyo.

Distribution.--Honshu.

This species is close to $T$. kinoshitai Kono et Takahasi, but in $T$. kinoshitai the subcallus. is denuded, shiny black and the frons is broad. Also $T$. matsumotoensis is related to $T$. cordiger Meigen and $T$. loukashkini Philip from which it may be easily distinguished by its narrow maxillary palpus and narrow frons.

\title{
Description of Sarcophaga koreaensis n. sp. (Sarcophagidae, Diptera) collected in Taegu, Korea
}

By

Soung Ho Park ${ }^{1)}$ and Rokuro Kano ${ }^{21}$

In Korea, Dr. Harujiro Kobayashi and Dr. Katsushige Hori have classified Korean flies into 6 families, 17 genera and 45 species before World War II. Since then no further works on the family have been done in Korea.

During the period from April of 1959 to September of 1960, Park had made an intensive collection of flies in the Taegu area which amounted to 4844 specimens of Sarcophagidae.

A close examination of the specimens revealed that 3 species of Sarcophaga were new and 10 species were hitherto unreported from Korea.

The authors will describe one of these new species in the present paper.

\section{Sarcophaga koreaensis $\mathrm{n}$. sp.}

\author{
Male
}

Body length : $18 \mathrm{~mm}$

Head : Front about 2/3 (18:10) as wide as one eye; frontal vitta black; parafrontals about $1 / 2$ as wide as frontal vitta; parafrontals and parafacials with golden pollen; bucca with

1) 朴星湖 Department of Biology, Graduate School Kyung-pook University, Taegu, Korea

2) 加納六郎 Tokyo Medical and Dental University, Tokyo, Japan golden pollen and black hairs; frontal bristles 9 or 10 pairs; antennae black, 3rd segment with brownish pollen and length of 3rd segment twice that of 2nd; 3 regular rows of black setae present on postocular part; metacephalon with numerous long grayish white hairs; palpi black.

Thorax: Scutum with golden pollen and with 3 black longitudinal stripes; acrostichals $0+1$; dorsocentrals $4-5+4-5$.

Wings: Costal spine indistinct; $r_{1}$ without setae; ventral side with 3 setae on the basal node of $r_{4+5} ; r_{4+5}$ with 8 setae located dorsally about half way from basal node to $r-m$.

Legs: Black; fore femur with a pair of rows of bristles on dorsal surface and with a row of bristles on ventral surface; mid femur with a row of relatively short bristles and long fine hairs on ventral surface and with 3 or 4 short bristles on lateral surface; hind femur with a pair of rows of bristles on dorsal surface and with a row of bristles and long hairs on ventral surface; hind tibia with numerous long hairs curved at apex on ventral surface and with a row of bristles and 3 pairs or 4 pairs of long bristles on dorsal surface.

Abdomen: With black and golden gray checkered pattern; 1 pair of lateral marginal bristles each on 2nd and 3rd tergites; 1 pair 
得 生動 物 1961 年 Vol. 12 No. 2

Sarcophaga koreaensis n. sp.
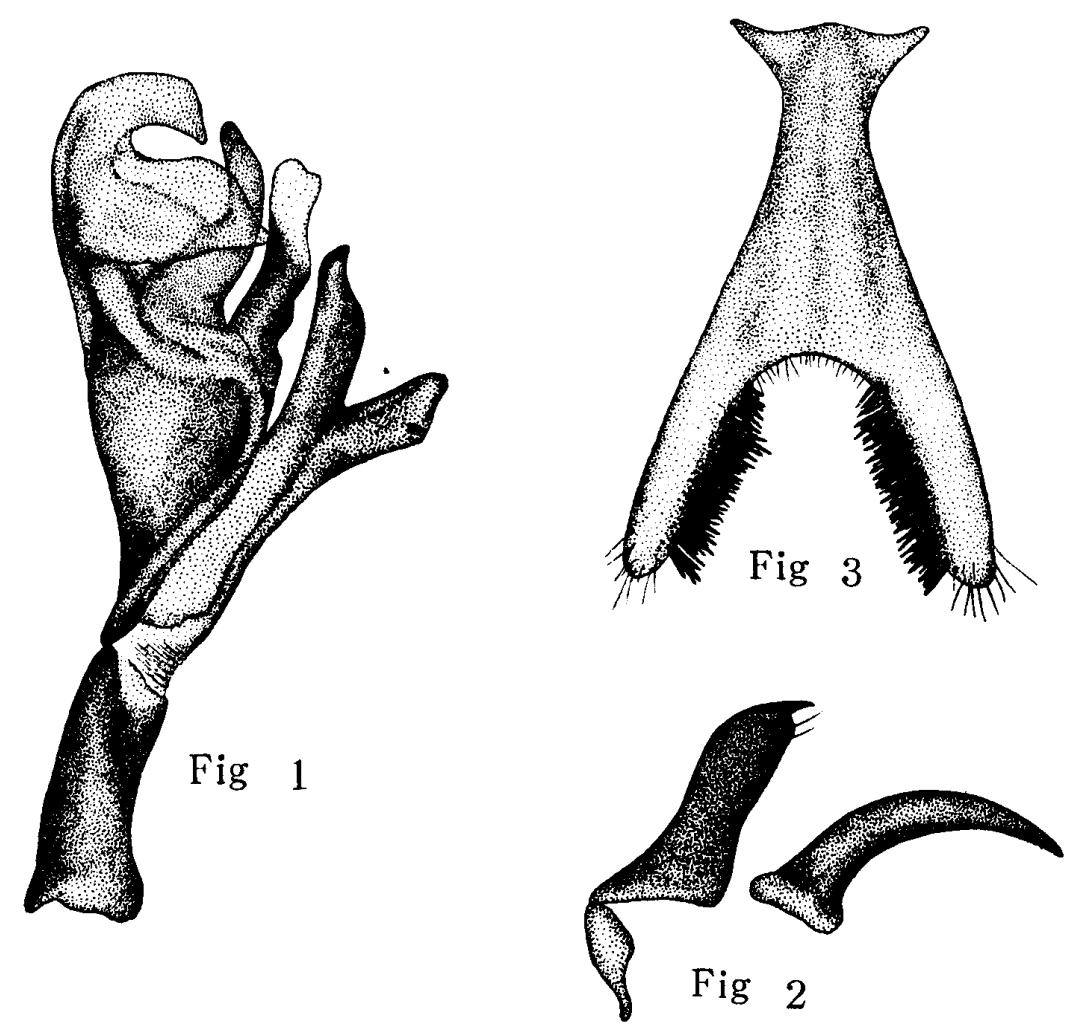

Sarcophaga basalis
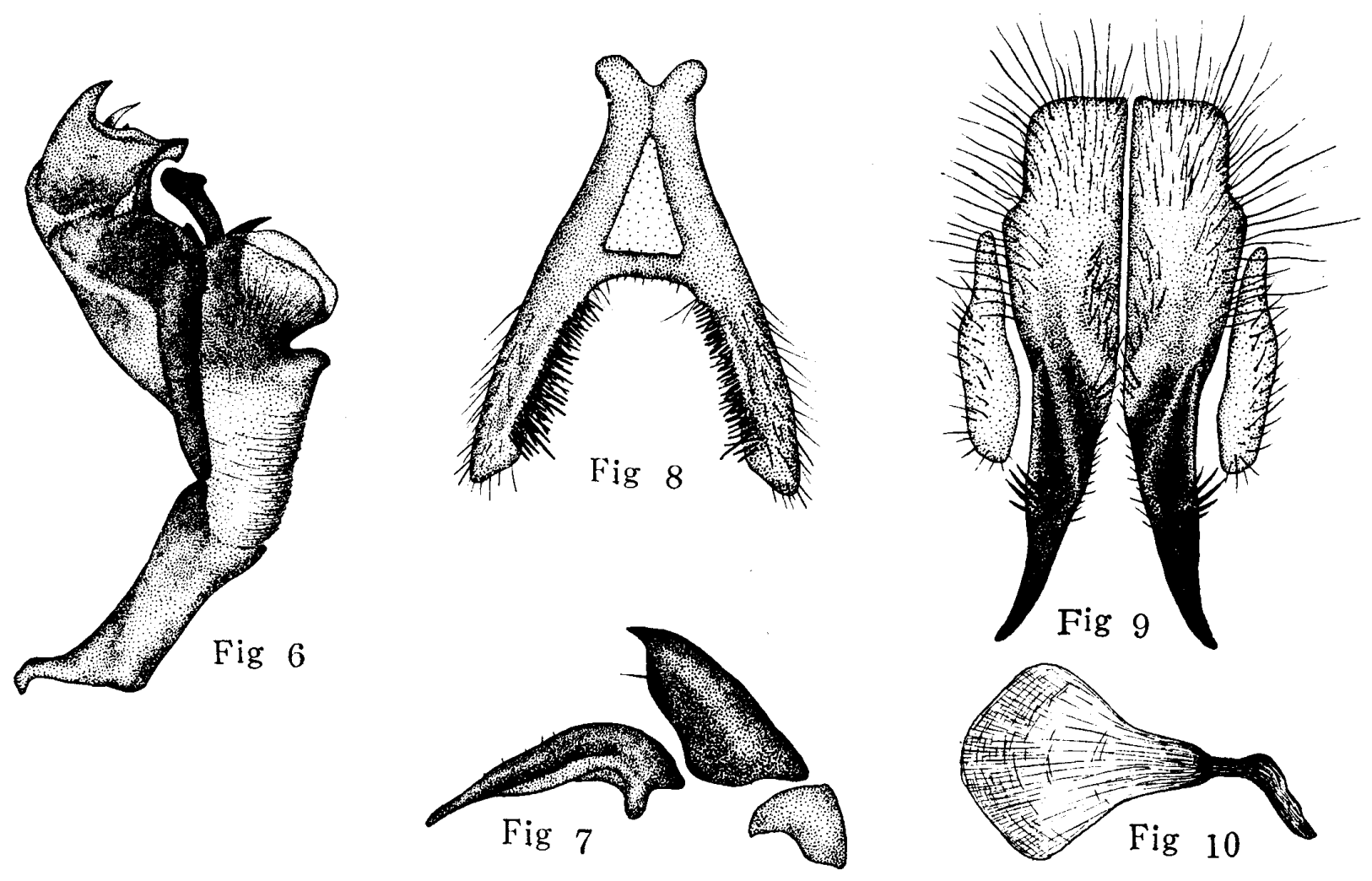

Fig. 1, 6: phallosomes

Fig. 4, 9: forceps

Fig. 2, 7 : parameres

Fig. $3,8: 5$ th sternites

Fig. 5, 10: ejaculatory apodemes
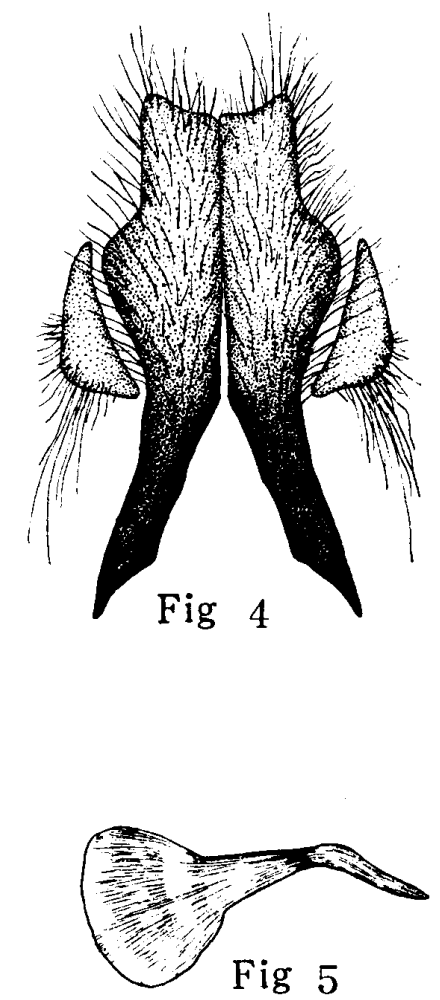


$$
\text { 葦生動物 } 1961 \text { 年 Vol. } 12 \text { No.2 }
$$

of median marginals and 3 pairs of lateral marginal bristles on 4 th tergite : 5th tergite a continuous row of marginal bristles; 1st genital tergite black and covered with grayish pollen and without marginal bristles; 2nd genital tergite shiny black and with numerous weak black hairs; genitalia as shown in Fig. $1 \sim 5$.

\section{Types}

Holotype: Male ; Mt. Pal-gong in Taegu, Korea, July 13, 1960 ; collected by S. H. Park, the type specimen is preserved in Department of Zoology, Kyung-pook University.
Paratypes: 2 Males; Mt. Pal-gong (Taegu), July 13, '60; 2 Males; Mt. Pal-gong, August 16, '60 ; collected by S. H. Park.

Remarks: Park collected this species in the forests of Mt. Pal-gong of $900 \mathrm{~m}$ above the sea-level. This species is closely related to Sarcophaga basalis Walker, 1859 in external aspect, but it is clearly distinguished from $S$. basalis by the shape of the genitalia, forceps and 5th sternite. (Fig. 6 10)

This species and $S$. basalis were the largest species among sarcophagid flies collected by $\mathrm{S}$. H. Park.

\section{タイプ室のゴキブリ}

井上(1959)の東京の某ビルデイングにおけるゴキブリ 駆除実験成績に上る上, 食堂, 炊事場についでタイプ室 に多くの死がいがみられているその理由として，タイプ 室には何等かの意味で彼等の食品が存在するものと推考 されている. タイプ室に棲息数が多いのが，果してどの ような原因に基くものか実験を試みた。まずタイプ室の 誘引源として考えられるものにタイプ原紙があつたの で，これに対するクロゴキブリ Periplaneta fuliginosa 及チャバネゴキブリ Blattella germanica の嗜好性を しらべた，この結果は両種上も打ち損じの原紙に修正液 を塗布したものに最も摂食痕が多く, わら半紙に修正液 を塗つたものがこれに次ぎ，新しいタイプ原紙には食痕
が少かつた。

タイプ原紙，修正液の成分をしらべてみたところ，原 紙は和紙にコロジオンとオレイン酸とヒマシ油を附着さ せたものであり，修正液はコロジオンとオレイン酸とブ タノールの混合したものであることが分つた。

そこでコロジオンとオレイン酸を別々に紙に塗布して 供試した結果，コロジオンは全く食痕がみられなかつた が，オレイン酸を好った方に泣多くの食痕がみとめられ た. 以上の観察からタイプの原紙や修正液のオレイン酸 が，誘引源と㳊り，これがタイプ室にゴキブリの棲息数 の多い原因の一つヒなっているものと考元た。

(予研・昆虫, 野口主子) 